\title{
Oxalyl Boronates Enable Modular Synthesis of Bioactive Imidazoles
}

\author{
C. Frank Lee, Aleksandra Holownia, James M. Bennett, Jonathan M. Elkins, Jeffrey D. St. Denis, \\ Shinya Adachi, Andrei K. Yudin*
}

Abstract: Herein, we describe the preparation of oxalyl boronate building blocks and their application for the construction of heterocycles. The oxalyl unit, readily accessible through commercially available starting materials, enables a modular approach for the synthesis of imidazoles. A variety of aromatic, heteroaromatic, and alkyl carboxaldehydes were condensed with oxalyl boronates to afford substituted boryl imidazoles in a regiocontrolled fashion. Subsequent Pd-catalyzed cross-coupling with haloarenes furnished the desired trisubstituted imidazole scaffolds. To demonstrate the utility of these scaffolds, we have synthesized potent inhibitors of the serine/threonine-protein kinase STK10.

Rapid access to small organic molecules continues to attract the attention of synthetic chemists and chemical biologists.[1] Approaches that utilize readily accessible reagents are deemed particularly useful. In this regard, cross-coupling reactions offer a versatile path to generate collections of diverse compounds,[2] in which rotatable bonds serve as connectors between variously substituted building blocks. The ultimate goal of these endeavors is to deliver molecules capable of productive interactions with the binding pockets on protein surfaces. The nature of small molecule/protein interactions ranges from hydrophobic contacts to hydrogen bonds.[3] The most useful molecules are often based on either linear (e.g. Gleevec, Figure 1) or "hub" scaffolds (e.g. Celebrex, Figure 1). The hub systems are especially attractive because rotatable bonds emanating from the central ring offer different vectors to interact with the grooves on protein surfaces and in binding sites. However, the construction of hub scaffolds, particularly azacycles, in a regiochemically controlled fashion continues to be a challenge, one that often requires elaborate precursors and harsh reaction conditions.[4] We became interested in creating a flexible approach to the synthesis of hub architectures. Herein, we highlight oxalyl MIDA ( $N$ - methyliminodiacetic acid) boronates in the synthesis of hub- based scaffolds, and demonstrate their utility for the design of orphan kinase inhibitors.

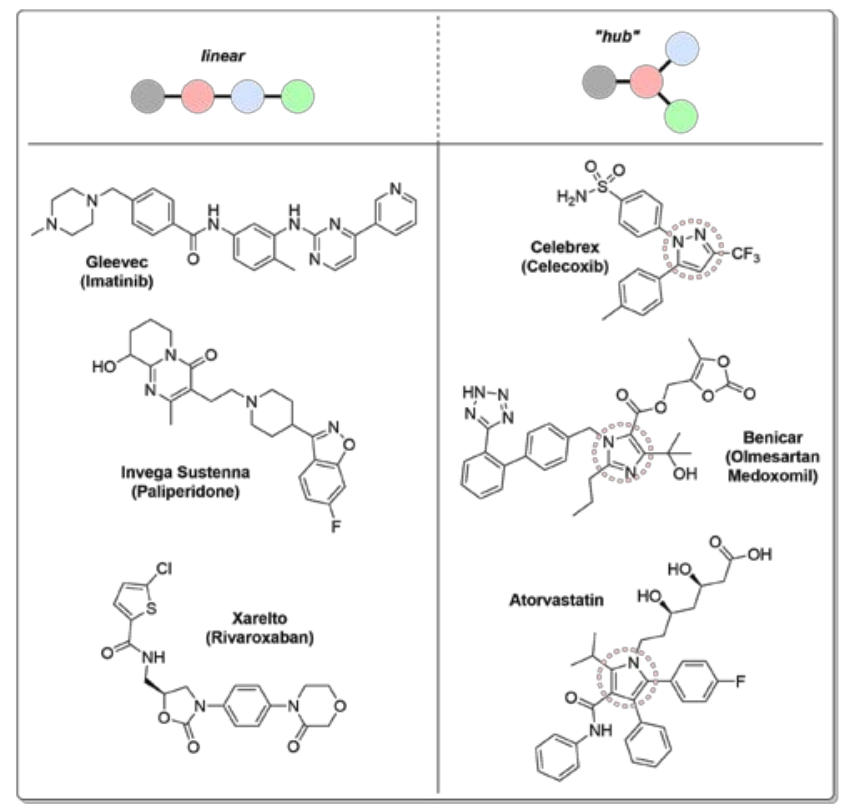

Figure 1. Select therapeutic agents with linear and "hub" topologies.[5]

Imidazoles have found widespread application in medicinal chemistry as a central heterocyclic unit for biologically active small molecules, pharmaceuticals, natural products, and application in materials chemistry.[6] A wide variety of classical methods for constructing the imidazole scaffold have been reported.[4e],[7] Given the role of 1,2-dicarbonyl compounds in synthesis, we became interested in merging the boronate and diketone functionalities in the same molecule. Treatment of vinyl MIDA boronates (2) with catalytic OsO4 and $\mathrm{N}$-methylmorpholine $\mathrm{N}$ - oxide (NMO) afforded dihydroxylated MIDA boronates (3a-h) in high yields (Table 1).[8] 1,2-Boryl alcohols are typically unstable motifs due to the facile borono-Peterson-type elimination that is commonly observed.[9] However, the stability of $\mathbf{3}$ is attributed to the MIDA ligand on the boron atom, shielding the empty p-orbital from the elimination pathway.

The oxidation of $\mathbf{3}$ with Dess-Martin periodinane (DMP) after 1 hour furnished the desired oxalyl boronates (4a-h) in good to excellent yields as bench-stable solids (Table $\mathbf{1})$. This route is not only amenable to electron-rich (4g-h), electron-poor aromatics (4f), and alkyl (4a-c) derivatives, but also highly scalable as the reactions were performed on a $1.0-5.0 \mathrm{~g}$ scale without significant effect on product yields.

Table 1. Synthesis of oxalyl MIDA boronates ${ }^{[a]}$ 


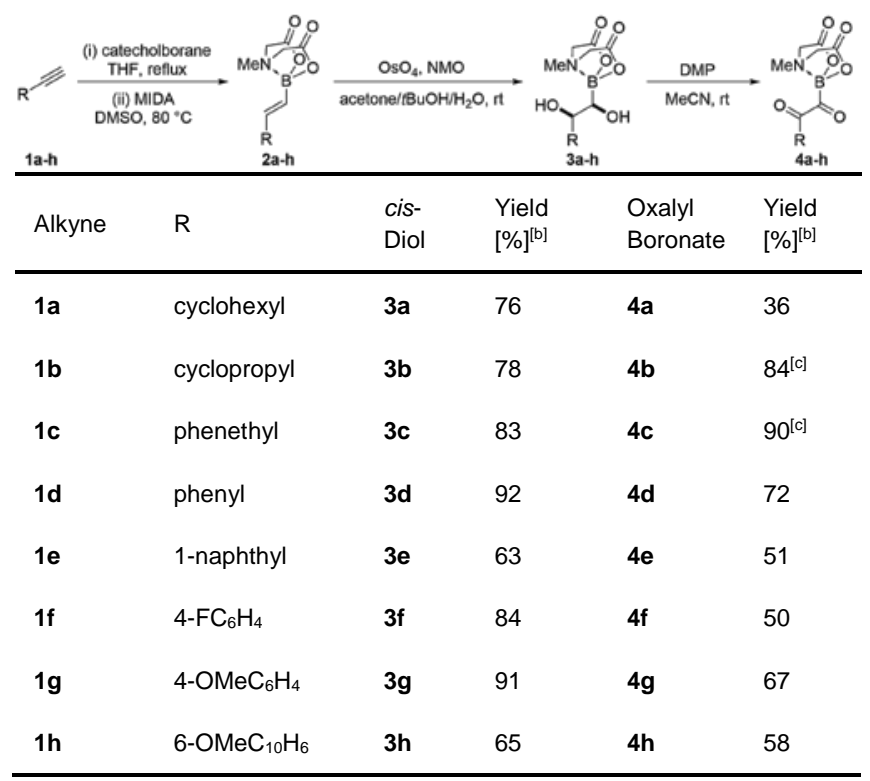

[a] Reactions were carried out using 1.0 equiv of alkyne, 1.5 equiv of catecholborane in tetrahydrofuran (THF: $0.5 \mathrm{M})$ at $65^{\circ} \mathrm{C}$ for 24 hours; 1.5 equiv of $N$-methyliminodiacetic acid (MIDA) in dimethylsulfoxide (DMSO: $0.1 \mathrm{M}$ ) at $80^{\circ} \mathrm{C}$ for $1-5$ hours. Dihydroxylation was achieved using 1-2 mol\% of osmium tetroxide ( $4 \mathrm{wt} \%$ in $\mathrm{H}_{2} \mathrm{O}$ ) and 1.5 equiv of $\mathrm{N}$-methylmorpholine $\mathrm{N}$-oxide (NMO) in an 18:1:1 solvent ratio of acetone/tert-butanol/water $(0.05 \mathrm{M})$. Oxidations were executed using 2.2 equiv of Dess-Martin periodinane (DMP) in acetonitrile (MeCN: $0.1 \mathrm{M}$ ) at room temperature for 1 hour. [b] Yield is that of isolated product after silica gel chromatography. [c] Products were unstable towards column chromatography; NMR yield calculated using trimethoxybenzene as the internal standard.

We investigated the synthetic utility of oxalyl boronates in the synthesis of imidazoles. In the presence of NH4OAc and benzaldehyde, phenyl oxalyl boronate (4d) smoothly converted to the corresponding 2,4,5-trisubstituted borylated imidazole in a highly regioselective fashion (Scheme 1, 5a). Contrary to classical Debus conditions,[7d],[10] our modified method of utilizing AcOH as the reaction medium allowed the reaction to occur at room temperature as the borylated imidazole product was formed after $1-2$ hours without any decomposition or oxazole byproduct formation.[11] This allowed us to modularly control the C2 position on the heterocycle wherein a wide variety of aldehydes, including alkyl $\mathrm{N}$-Boc protection aldehydes $(\mathbf{5 h})$, were well tolerated in the synthesis without any

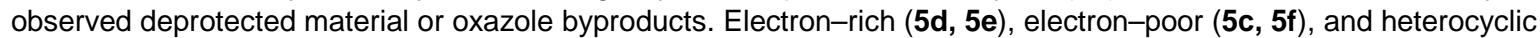

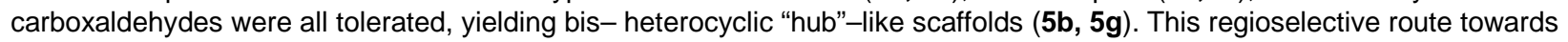
borylated imidazoles enables the heterocycle to become a hub of controlled functionalization, where each spoke is introduced in one step. In addition, the boryl imidazole products are intensely coloured, highlighting the utility of these compounds as fluorescent reporters for covalent inhibitors or other photophysical/chemical applications.[12]

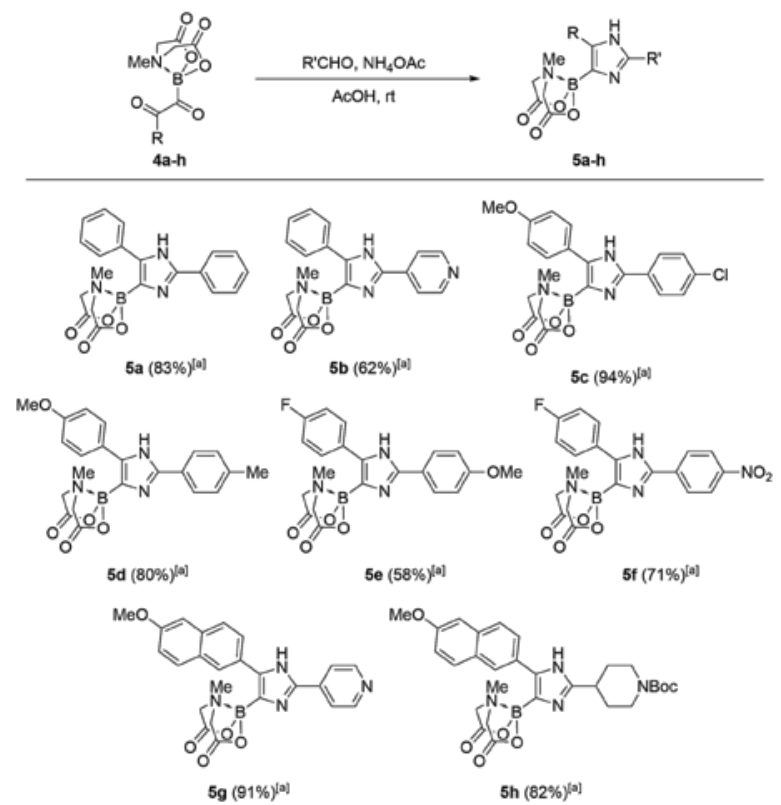


Scheme 1. Scope of borylated imidazoles. Reactions were carried out using 1.0 equiv of oxalyl boronate, 1.1 equiv of aldehyde (R'CHO), 15 equiv of ammonium acetate $\left(\mathrm{NH}_{4} \mathrm{OAc}\right)$ in acetic acid $(\mathrm{AcOH}$ : $0.1 \mathrm{M})$ at room temperature for $1-2$ hours. [a] Yield is that of isolated product after silica gel chromatography. Boc = tert-Butyloxycarbonyl.

Finally, with the C2 and C5 positions functionalized, the resulting borylated imidazoles were subjected to standard cross- coupling conditions with aryl bromides to complete a facile method for generating densely functionalized imidazoles. Unfortunately, employing cross-coupling conditions for MIDA- boronates (variations of Buchwald precatalysts)[13] led to quantitative formation of the undesired protodeboronation product and trace amounts of the desired product by LC/MS analysis (See Supporting Information). The boryl imidazole scaffold, similar to the analogous 2-boryl pyridine system, is notoriously prone to protodeboronation under cross-coupling conditions due to the electronic nature of the heterocycle and the position of the boronic acid/ester group on the ring.[14] Employing the "slow-release" method developed by Burke, et. al.[15] also led to exclusive protodeboronation product. An improved product ratio as indicated by LC/MS analysis was observed with a modified "slow- release" method. However, switching to $\mathrm{Pd}(\mathrm{dppf}) \mathrm{Cl} 2$ and sodium carbonate in a 10:1 mixture of DMF/H2O led to the best product ratio (See Supporting Information) where the products were isolated by reverse-phase column chromatography (Scheme 2).

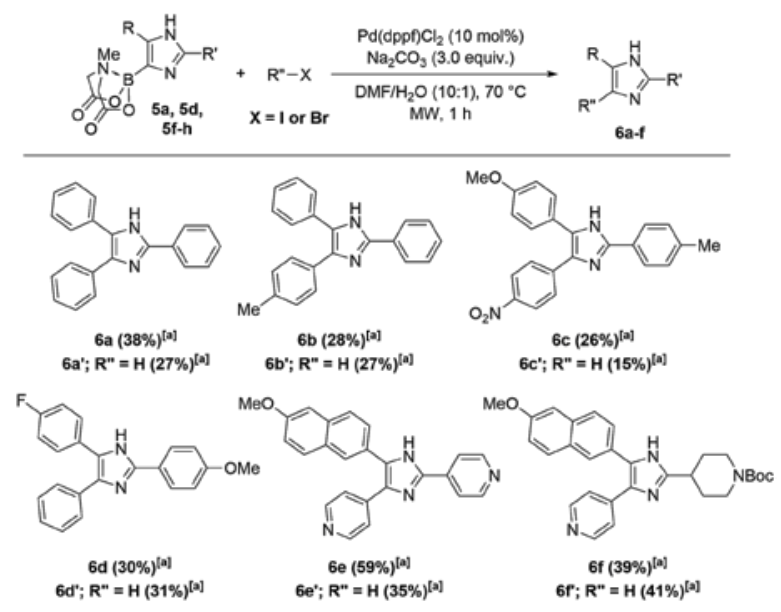

Scheme 2. Suzuki-Miyaura cross-coupling of borylated imidazoles. Reactions were achieved using 1.0 equiv of boryl imidazole, 1.5 equiv of R"X, 10 mol\% of $\mathrm{Pd}(\mathrm{dppf}) \mathrm{Cl}_{2}, 3.0$ equiv of sodium carbonate $\left(\mathrm{Na}_{2} \mathrm{CO}_{3}\right)$ in a $10: 1$ solvent mixture of dimethylformamide (DMF) and water at $70{ }^{\circ} \mathrm{C}$ for 1 hour in a Biotage microwave reactor. [a] Yield is that of isolated product after reverse-phase silica gel chromatography. $\mathrm{MW}=$ microwave, $\mathrm{Boc}=$ tert-Butyloxycarbonyl.

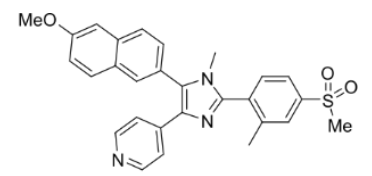

STK10 : SB-633825

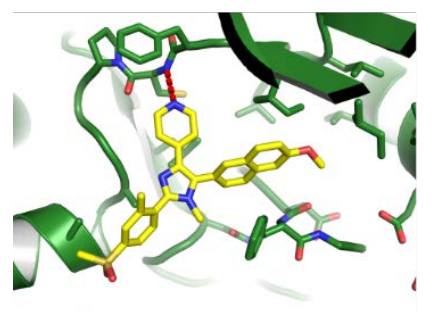<smiles>COc1ccc2ccc(-c3[nH]cnc3-c3ccncc3)cc2c1</smiles>

SLK : SB-440719

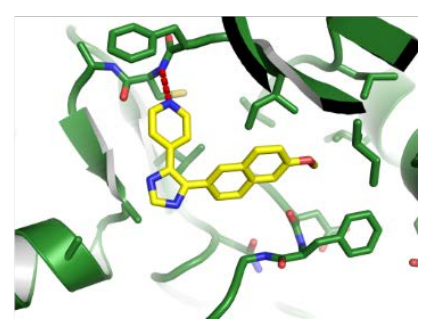

Figure 2. X-ray co-crystal structures of STK10:SB-633825 (PDB 4USD, left) and SLK:SB-440719 (PDB 4USF, right) ${ }^{[22]}$ that were used for compound design.

To highlight the versatility of our approach, we decided to use this method to tackle the kinase STK10, a serine/threonine- protein kinase highly expressed in lymphocytes which is involved in regulating lymphocyte migration,[16] towards the discovery of a chemical probe. STK10 and the related kinase SLK are involved in regulating PLK1 (polo-like kinase 1).[17] PLKs are critical regulators of cell cycle progression, mitosis, cytokinesis, and DNA damage response.[18] Kinases are well-known drug targets due to their roles in the regulation of cellular physiology and pathology,[19] and as of January 2016 there were 28 FDA-approved drugs that target kinases.[20] With more than 500 protein kinases in the human genome, many of which have strong links to fundamental cellular processes, there is a strong need for efficient methods of elaborating kinase inhibitors. After analyzing the co-crystal structures of SB$\mathbf{6 3 3 8 2 5}$ and SB-440719 (Figure 2) where SB- $\mathbf{6 3 3 8 2 5}$ inhibited STK10 to 44\% maximal activity at $100 \mathrm{nM}$,[21] we were prompted to 
use oxalyl boronates to rapidly generate a series of STK10 inhibitors by varying the C2 position of the heterocycle. This would allow the development of a ligand efficient small molecule inhibitor by increasing $\mathrm{H}$-bond interactions with amino acid residues or on the protein backbone.

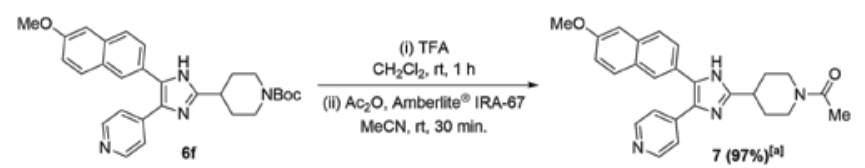

Scheme 3. Synthesis of $N$-acyl piperidine derivative. Reaction was carried out using 1.0 equiv of imidazole $6 \mathbf{f}$ and 20 equiv of trifluoroacetic acid (TFA) in dichloromethane $(0.1 \mathrm{M})$ at room temperature for 1 hour. Followed by 1.0 equiv of Amberlite ${ }^{8}$ IRA-67 resin and 1.5 equiv of acetic anhydride $\left(\mathrm{Ac}_{2} \mathrm{O}\right)$ in acetonitrile $(\mathrm{MeCN}: 0.1 \mathrm{M})$ at room temperature for 30 minutes. [a] Yield is that of isolated product after reverse-phase silica gel chromatography. Boc = tert-Butyloxycarbonyl.

Compounds 6 e and 7 (Scheme 3) were tested against STK10 and SLK. Preliminary results have shown that 6 e and 7 exhibited $K i$ values of $250 \mathrm{nM}$ and $130 \mathrm{nM}$ against STK10, and $340 \mathrm{nM}$ and $180 \mathrm{nM}$ against SLK, respectively (Figure 3, See Supporting Information). The introduction of a heteroatom on the $\mathrm{C} 2$ position (6e) lowered the $K i$ value, presumably due to an increase in $\mathrm{H}$-bond interactions. However, swapping the pyridyl group with an $\mathrm{N}$-acyl piperidyl group (7) resulted in an improved $\mathrm{Ki}$ value. With the added flexibility of the saturated heterocycle (7) compared to a flat aromatic group (6e), it may allow the molecule to adopt a more optimal geometry in the binding pocket. With the ease of modifying the groups on the imidazole core, efforts to generate a more comprehensive library of compounds are currently ongoing.

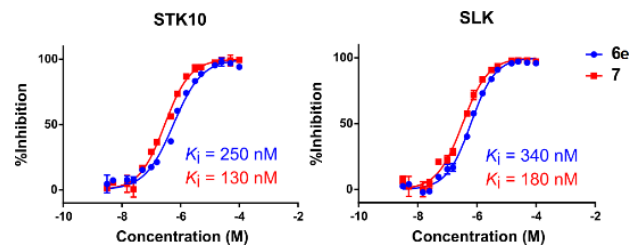

Figure 3. Percentage inhibition for compounds 6 e and $\mathbf{7}$ against STK10 and SLK as measured in a binding-displacement assay. Each measurement was measured in duplicate and repeated on a subsequent day. One example of each duplicate is shown.

In summary, we have developed a modular approach towards the construction of densely functionalized imidazole scaffolds through our oxalyl boronate technology. The use of a multicomponent double condensation reaction with a wide range of aldehydes followed by a cross-coupling of MIDA-boryl imidazoles provided an efficient method to regioselectively vary the groups on the central heterocycle. Current investigations are aimed at leveraging oxalyl boronates to provide further insight into the physiological significance of novel imidazole inhibitors and target validation of the protein kinase STK10.

\section{Acknowledgements}

We would like to thank the Natural Science and Engineering Research Council (NSERC), the Canadian Institute of Health Research (CIHR), the Canadian Foundation for Innovation, project number 19119, for financial support, and the Ontario Research Fund for funding of the Centre for Spectroscopic Investigation of Complex Organic Molecules and Polymers. C.F.L. would like to thank the Government of Ontario and OGS for QEII funding and NSERC for PGS-D funding. The SGC is a registered charity (number 1097737) that receives funds from AbbVie, Bayer Pharma AG, Boehringer Ingelheim, Canada Foundation for Innovation, Eshelman Institute for Innovation, Genome Canada, Innovative Medicines Initiative (EU/EFPIA) [ULTRA-DD grant no. 115766], Janssen, Merck \& Co., Novartis Pharma AG, Ontario Ministry of Economic Development and Innovation, Pfizer, São Paolo Research Foundation-FAPESP, Takeda, and Wellcome Trust [106169/ZZ14/Z].

Keywords: heterocycle $\bullet$ synthetic methods $\bullet$ cross-coupling $\bullet$ biological activity $\bullet$ inhibitors

[1] (a) S. V. Ley, I. R. Baxendale, Nat. Rev. Drug Discov. 2002, 1, 573-586, and references therein; (b) J. Wencel-Delord, F. Glorius, Nat. Chem. 2013, 5, 369375; (c) S. Dandapani, A. R. Germain, I. Jewett, S. I. Quement, J.-C. Marie, G. Municipinto, J. R. Duvall, L. C. Carmody, J. R. Perez, J. C. Engel, J. Gut, D. Kellar, J. L. Siquiera-Neto, J. H. McKerrow, M. Kaiser, A. Rodriguez, M. A. Palmer, M. Foley, S. L. Schreiber, B. Munoz, ACS Med. Chem. Lett. 2014, 5, 149153.

[2] (a) S. Tasler, J. Mies, M. Lang, Adv. Synth. Catal. 2007, 349, 2286-2300; (b) J. Bariwal, E. Van Der Eycken, Chem. Soc. Rev. 2013, 42, 9283-9303; (c) R. Jana, T. P. Pathak, M. S. Sigman, Chem. Rev. 2011, 111, 1417-1492.

[3] C. Bissantz, B. Kuhn, M. Stahl, J. Med. Chem. 2010, 53, 5061-5084.

[4] (a) X. Yang, P. Knochel, Chem. Commun. 2006, 20, 2170-2172; (b) C. Sämann, E. Coya, P. Knochel, Angew. Chem. Int. Ed. 2014, 53, 1430-1434; (c) F. Shibahara, E. Yamaguchi, T. Murai, J. Org. Chem. 2011, 76, 2680-2693; (d) F. Shibahara, T. Yamaguchi, E. Yamaguchi, T. Murai, J. Org. Chem. 2012, 77, 8815-8820; (e) F. Bellina, S. Cauteruccio, R. Rossi, J. Org. Chem. 2007, 72, 8543-8546; (f) J. C. Rech, M. Yato, D. Duckett, B. Ember, P. V. LoGrasso, R. G. Bergman, J. A. Ellman, J. Am. Chem. Soc. 2007, 129, 490-491; (g) A. K. Takle, M. J. B. Brown, S. Davies, D. K. Dean, G. Francis, A. Gaiba, A. H. Hird, F. D. King, P. J. Lovell, A. Naylor, A. D. Reith, J. G. Steadman, D. M. Wilson, Bioorg. Med. Chem. Lett. 2006, 16, 378-381; (h) J. M. Joo, B. Barry Touré, D. Sames, J. Org. Chem. 2010, 75, 4911-4920; (i) M. R. Grimmett in Comprehensive Heterocyclic Chemistry, Vol. 5 (Eds: A. R. Katritzky, C. W. Rees), Pergamon, 
Oxford, 1984, pp. 345; (j) A. V. Gulevich, A. S. Dudnik, N. Chernyak, V. Gevorgyan, Chem. Rev. 2013, 113, 3084-3213, and references therein; (k) R. L. Webb, J. J. Lewis, J. Heterocyclic Chem. 1981, 18, 1301-1303.

[5] N. A. McGrath, M. Brichacek, J. T. Njardarson, J. Chem. Educ. 2010, 87, 1348-1349.

[6] (a) M. Gaba, C. Mohan, Med. Chem. Res. 2016, 25, 173-210; (b) D. J. Newman, G. M. Cragg, K. M. Snader, J. Nat. Prod. 2003, 66, 1022-1037; (c) E. B. Anderson, T. E. Long, Polymer 2010, 51, 2447-2454; (d) R. S. Walmsley, A. S. Ogunlaja, M. J. Coombes, W. Chidawanyika, C. Litwinski, N. Torto, T. Nyokong, Z. R. Tshentu, J. Mater. Chem. 2012, 22, 5792-5800.

[7] (a) H. Bredereck, G. Theilig, Chem. Ber. 1952, 85, 88; (b) H. Debus, Justus Liebigs Ann. Chem. 1858, 107, 199-208; (c) D. Van Leusen, O. Oldenziel, A. Van Leusen, J. Org. Chem. 1977, 42, 3114-3118; (d) R. D. Crouch, J. L. Howard, J. L. Zile, K. H. Barker, J. Chem. Educ. 2006, 83, 1658-1660; (e) P. Loos, C. Ronco, M. Riedrich, H.-D. Arndt, Eur. J. Org. Chem. 2013, 16, 3290-3315; (f) Y.-B. Nie, L. Wang, M.-W. Ding, J. Org. Chem. 2012, 77, 696-700.

[8] G. A. Molander, R. Figueroa, Org. Lett. 2006, 8, 75-78.

[9] (a) D. S. Matteson, J. Organomet. Chem. 1999, 581, 51-65; (b) R. Ray, D. S. Matteson, Tetrahedron Lett. 1980, 21, 449-450.

[10] (a) J. Gising, M. T. Nilsson, L. R. Odell, S. Yahiaoui, M. Lindh, H. Iyer, A. M. Sinha, B. R. Srinivasa, M. Larhed, S. L. Mowbray, A. Karlén, J. Med. Chem. 2012, 55, 2894-2898; (b) G. Bratulescu, Synthesis 2009, 14, 2319-2320; (c) S. E. Wolkenberg, D. D. Wisnoski, W. H. Leister, Y. Wang, Z. Zhao, C. W. Lindsley, Org. Lett. 2004, 6, 1453-1456.

[11] Use of acetic acid at high temperatures was first reported by Davidson: the authors observed a substantial improvement in the formation of imidazole compared to reactions performed in alcoholic solvents: D. Davidson, M. Weiss, M. Jelling, J. Org. Chem. 1937, 2, 319-327.

[12] (a) J. Jayabharathi, V. Thanikachalam, N. Srinivasan, M. V. Perumal, Spectrochimica Acta Part A 2012, 90, 125-130; (b) R. Satapathy, Y.-H. Wu, H.-C. Lin, Org. Lett. 2012, 14, 2564-2567; (c) D. Zhao, J. Hu, N. Wu, X. Huang, X. Qin, J. Lan, J. You, Org. Lett. 2011, 13, 6516-6519; (d) W. Li, W. Lin, J. Wang, X. Guan, Org. Lett. 2013, 15, 1768-1771.

[13] (a) J. D. St. Denis, C. C. G. Scully, C. F. Lee, A. K. Yudin, Org. Lett. 2014, 16, 1338-1341; (b) J. D. St. Denis, A. Zajdlik, J. Tan, P. Trinchera, C. F. Lee, Z. He, S. Adachi, A. K. Yudin, J. Am. Chem. Soc. 2014, 136, 17669-17673.

[14] (a) E. Tyrrell, P. Brookes, Synthesis 2004, 4, 469-483, and references therein; (b) K. Billingsley, S. L. Buchwald, J. Am. Chem. Soc. 2007, 129, 3358-3366; (c) P. A. Cox, A. G. Leach, A. D. Campbell, G. C. Lloyd-Jones, J. Am. Chem. Soc. 2016, 138, 9145-9157; (d) D. M. Knapp, E. P. Gillis, M. D. Burke, J. Am. Chem. Soc. 2009, 131, 6961-6963; (e) A. Bouillon, J.-C. Lancelot, J. S. d.O. Santos, V. Collot, P. R. Bovy, S. Rault, Tetrahedron $2003,59,10043-10049$.

[15] (a) G. R. Dick, E. M. Woerly, M. D. Burke, Angew. Chem. Int. Ed. 2012, 51, 2667-2672; (b) J. A. Gonzalez, O. Maduka Ogba, G. F. Morehouse, N. Rosson, K. N. Houk, A. G. Leach, P. H.-Y. Cheong, M. D. Burke, G. C. Lloyd-Jones, Nat. Chem. 2016, doi:10.1038/nchem.2571; (c) A. J. J. Lennox, G. C. LloydJones, Chem. Soc. Rev. 2014, 43, 412-443; (d) J. E. Grob, J. Nunez, M. A. Dechantsreiter, L. G. Hamann, J. Org. Chem. 2011, 76, 10241-10248.

[16] (a) N. V. Belkina, Y. Liu, J. J. Hao, H. Karasuyama, S. Shaw, Proc. Natl. Acad. Sci. USA 2009, 106, 4707-4712; (b) S. Kuramochi, T. Miroguchi, K. Kuida, J. Endo, K. Semba, E. Nishida, H. Karasuyama, J. Biol. Chem. 1997, 272, 22679-22684; (c) R. Viswanatha, P. Y. Ohouo, M. B. Smolka, A. Bretscher, J. Cell. Biol. 2012, 199, 969-984; (d) J. Endo, N. Toyama-Sorimachi, C. Taya, S. Kuramochi-Miyagawa, K. Nagata, K. Kuida, T. Takashi, H. Yonekawa, Y. Yoshizawa, N. Miyasaka, H. Karasuyama, FEBS Lett. 2000, 468, 234-238.

[17] (a) S. A. Walter, R. E. Cutler Jr., R. Martinez, M. Gishizky, R. J. Hill, J. Biol. Chem. 2003, 278, 18221-18228; (b) H. Ellinger-Ziegelbauer, H. Karasuyama, E. Yamada, K. Tsujikawa, K. Todokoro, E. Nishida, Genes Cells 2000, 5, 491-498.

[18] (a) D. M. Lowery, D. Lim, M. B. Yaffe, Oncogene 2005, 24, 248-259; (b) B. C. M. van de Weerdt, R. H. Medema, Cell Cycle 2006, 5, 853-864.

[19] B. Klebl, G. Müller, M. Hamacher in Protein Kinases as Drug Targets, Wiley-VCH Verlag GmbH \& Co., 2011.

[20] P. Wu, T. E. Nielsen, M. H. Clausen, Drug Discov. Today 2016, 21, 5-10.

[21] J. M. Elkins, V. Fedele, M. Szklarz, K. R. Abdul Azeez, E. Salah, J. Mikolajczyk, S. Romanov, N. Sepetov, X.-P. Huang, B. L. Roth, A. Al Haj Zen, D. Fourches, E. Muratov, A. Tropsha, J. Morris, B. A. Teicher, M. Kunkel, E. Polley, K. E. Lackey, F. L. Atkinson, J. P. Overington, P. Bamborough, S. Müller, D. J. Price, T. M. Willson, D. H. Drewry, S. Knapp, W. J. Zuercher, Nat. Biotech. 2016, 34, 95-103. 